\title{
New TitLES
}

Prepared by Roy John

$\dagger$ Available for review * Assigned

Currency Codes - CAD Canadian Dollars, USD U.S. Dollars, EUR Euros, AUD Australian Dollars.

\section{ZOOLOGY}

Amphibians and Reptiles of the West Indies: Descriptions, Distributions, and Natural History. By Albert Schwartz and Robert W. Henderson. 2009. University Press, of Florida, 15 NW 15th Street, Gainesville, Florida 32611. 714 pages. 79.95 USD, Cloth.

Guide and Reference to the Amphibians of Western North America (North of Mexico) and Hawaii. By R. D. Bartlett and Patricia P. Bartlett. 2009. University Press of Florida, 15 NW 15th Street, Gainesville, Florida 32611. 256 pages. 29.95 USD, Paper.

Adventures Among Ants: A Global Safari with a Cast of Trillions. By Mark Moffett. 2010 University of California Press, 2120 Berkeley Way, Berkeley, California 94704-1012. 29.95 USD.

Among the Great Apes: Adventures on the Trail of Our Closest Relatives. By Paul Raffaele. 2010. Smithsonian Books, P.O. Box 37012, MRC 513, Capital Gallery, Suite 6001, Washington, DC 20013-7012. 384 pages. 26.99 USD.

Ecological and Behavioral Methods for the Study of Bats. By Thomas H. Kunz. 2009. Johns Hopkins University Press 2715 North Charles Street, Baltimore, Maryland 21218-4363. 100.00 USD.

The Private Lives of Birds: A Scientist Reveals the Intricacies of Avian Social Life. By Bridget Stutchbury. 2010. Walker \& Company, 175 Fifth Avenue, New York, New York 10010. 272 pages. 25.00 USD.

* Identifying and Feeding Birds. By Bill Thompson III. 2010. Houghton Mifflin Harcourt Publishing Company, 222 Berkeley Street, Boston, Massachusetts 02116. 246 pages. USD, Paper.

Bird Songs Bible: The Complete Illustrated Reference for North American Birds. By Les Beletsky. Chronicle Books/ Cornell Lab of Ornithology's Macaulay Library. 680 Second Street San Francisco, California 94107. 125.00 USD.

Phillipps' Field Guide to the Birds of Borneo: Sabah, Sarawak, Brunei and Kalimantan. By Quentin and Karen Phillipps. John Beaufoy Publishing Limited, 11 Blenheim Court, 316 Woodstock Road, Oxford OX2 7NS, England. 368 pages. 29 EUR.

Birds of Cape May. By Kevin T. Karlson. 2010. Schiffer Publishing, 4880 Lower Valley Road, Atglen, Pennsylvania 19310. 256 pages. 49.99 USD, Cloth.

Birds of the Middle East: Second Edition. By Richard Porter and Simon Aspinall. 2010. Princeton University Press, 41 William Street, Princeton, New Jersey 08540. 400 pages. 39.50 USD Paper.
The Nesting Season: Cuckoos, Cuckolds, and the Invention of Monogamy. By Bernd Heinrich, 2010. Belknap: Harvard University Press 79 Garden Street, Cambridge, Massachusetts 02138. 29.95 USD.

The Star-Crossed Stone: The Secret Life, Myths, and History of a Fascinating Fossil. By Kenneth J. McNamara, 2010. University of Chicago Press, 1427 East 60th Street Chicago, Illinois 60637272 pages. 27.50 USD, Cloth.

The Rise of Horses: 55 Million Years of Evolution. By Jens Lorenz Franzen. 2010. Johns Hopkins University Press 2715 North Charles Street, Baltimore, Maryland 21218-4363. 65 USD

Insectopedia . By Hugh Raffles.2010. Pantheon [Random House] 1745 Broadway, 3rd Floor, New York, New York 10019. 29.95 USD.

The Wild Mammals of Japan. By S. D. Ohdachi, Y. Ishibashi, M.A. Iwasa and T. Saitih. (Editors). 2010. Shoukadoh Book Sellers. Kyoto, Japan. 544 pages. About 61.73 USD (plus shipping), Cloth.

The Biology of Small Mammals. By Joseph Merritt. 2010. Johns Hopkins University Press, 2715 North Charles Street, Baltimore, Maryland 21218-4363. 60 USD.

Guide and Reference to the Snakes of Western North America (North of Mexico) and Sharks and Rays of Australia; 2nd Edition. By Peter R. Last and John D. Stevens. 2009. CSRIO Publishing, Box 1139, Collingwood Victoria 3066, Australia 644 pages. 100.00 USD, Cloth.

Guide and Reference to the Turtles and Lizards of Western North America (North of Mexico) and Hawaii. By R. D. Bartlett and Patricia P. Bartlett. 2009. University Press of Florida, 15 NW15th Street, Gainesville, Florida 32611. 336 pages. 29.95 USD, Paper.

*Life in a Shell: A Physiologist's View of a Turtle. By Donald C. Jackson. 2011 Harvard University Press, 79 Garden Street, Cambridge, Massachusetts 02138. 192 pages. 29 USD, Cloth.

The Last Tortoise: A Tale of Extinction in Our Lifetime. Craig Stanford. 2010. Belknap: Harvard University Press, 79 Garden Street, Cambridge, Massachusetts 02138. 210 pages. 23.95 USD, Cloth.

The Whale: In Search of the Giants of the Sea. By Philip Hoare. 2010. Ecco: HarperCollins Harper Collins Publishers Ltd., 1995 Markham Road, Scarborough. 27.99 CAD. 


\section{BOTANY}

Carnivorous Plants and their Habitats (2 volumes). By Stewart McPherson. 2010. Redfern Natural History Productions. 61 Lake Drive Hamworthy, Poole, Dorset BH15 4LR England, UK. 1442 pages 34.99 GBP each Cloth.

Conifers of the World: The Complete Reference. By James Eckenwalder. 2009. Timber Press, 133 SW 2nd Avenue, Suite 450, Portland, Oregon 97204. 59.95 CAD.

Floral Diagrams: An Aid to Understanding Flower Morphology and Evolution. By Louis P. Ronse de Craene. 2010. Cambridge University Press, 32 Avenue of the Americas, New York, New York 10013-2473. \$130 USD.

Flora of North America North of Mexico. Volume 8: Magnoliophyta: Paeoniaceae to Ericaceae. Flora of North America Editorial Committee. 2009. Oxford University Press, 198 Madison Avenue, New York, New York 10016 USA. 95 USD.

Macrolichens of the Pacific Northwest (Second Edition). By Bruce McCune and Linda Geiser. 2009. Oregon State University Press 102 Adams Hall, Corvallis, Oregon 97331. 464 pages. 30.00 USD, Paper.

Trees of Panama and Costa Rica. By Richard Condit, Rolando Pérez \& Nefertaris Daguerre 2010.Princeton University Press, 41 William Street, Princeton, New Jersey 08540. 552 pages. Paper 45.00 USD, Cloth 85.00 USD.

\section{ENVIRONMENT}

*Assessment of Species Diversity in the Atlantic Maritime Ecozone. Edited by Donald F. McAlpine and Ian M. Smith. 2010. NRC Press in association with Agriculture and Agri-Food Canada, Environment Canada and the New Brunswick Museum Centre for Biodiversity Research. A Publication of the National Research Council of Canada Monograph Publishing Program, Ottawa, Ontario. 785 pages. 90 CAD.

Hawaii. By R. D. Bartlett and Patricia P. Bartlett. 2009. University Press of Florida, 15 NW 15th Street, Gainesville, Florida 32611. 29.95 USD, Paper.

\section{MiscellaneOUS}

Stolen World: A Tale of Reptiles. Smugglers and Skullduggery. Jennie Erin Smith. 2010. Crown Publishing, [Random House, Inc.] 280 Park Avenue (11-3), New York, New York 10017336 pages. \$25.00 USD.

Leaders in Animal Behavior: The Second Generation. By Lee C. Drickamer. 2010. Cambridge University Press, 32 Avenue of the Americas, New York, New York 100132473. 120.99 USD.

Second Nature: The Inner Lives of Animals. Jonathan P. Balcombe. 2010. Palsgrave Macmillan, 175 Fifth Avenue, New York, New York 10010. 27.00 USD.

Conservation Biology for All. By Navjot S. Sodhi and Paul R. Erlich. 2010. Oxford University Press, 198 Madison Avenue, New York, New York 10016 USA. 400 pages. 130.00 USD Cloth.

Emma Darwin: A Victorian Life. By James D. Loy and Kent M. Loy. 2010. University of Press of Florida Press, 15 NW 15th Street, Gainesville, Florida 32611. 448 pages. 39.95 USD.

Multiplicity in Unity: Plant Subindividual Variation and Interactions with Animals. By Carlos M. Herrera. 2009. University of Chicago Press, 1427 East 60th Street Chicago, Illinois 60637 USA. 110 USD.

Looking for a Few Good Males: Female Choice in Evolutionary Biology. By Erika Lorraine Milam. 2010 Johns Hopkins University Press 2715 North Charles Street, Baltimore, Maryland 21218-4363. 60 USD.

\section{RARE USED BOOK}

Audubon's Birds of America (the folio edition published between 1827 to 1838 ) for $\$ 10270000$ USD. With auction fees the total came to $\$ 11500000$ USD! The set went to British art dealer and birder Michael Tollemache. 